\title{
Advanced endoscopic resection using endoscopic submucosal dissection technique to resect a giant, lumen-occluding esophageal polyp
}

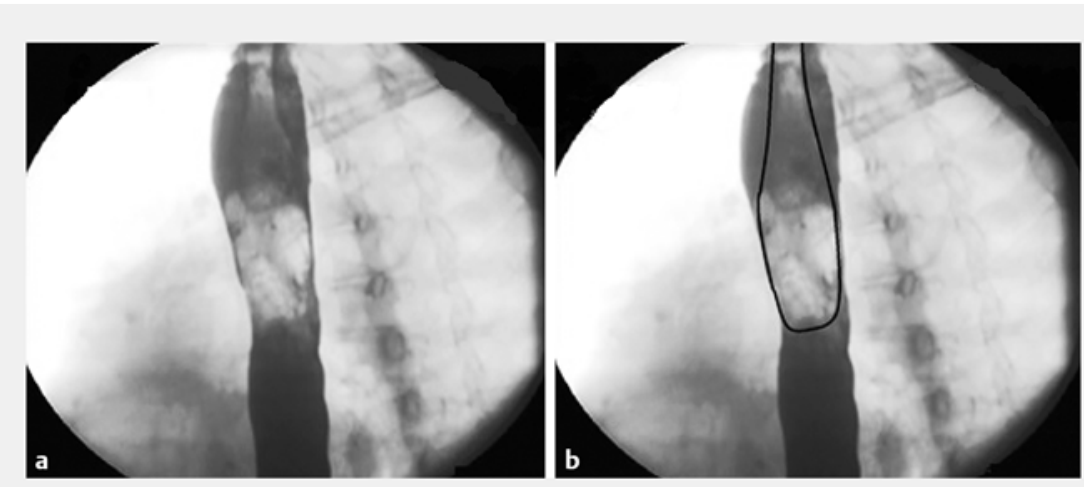

- Fig. 1 Esophagogram revealed an esophageal polyp, $12 \mathrm{~cm}$ in length and occupying $80 \%$ of the lumen.

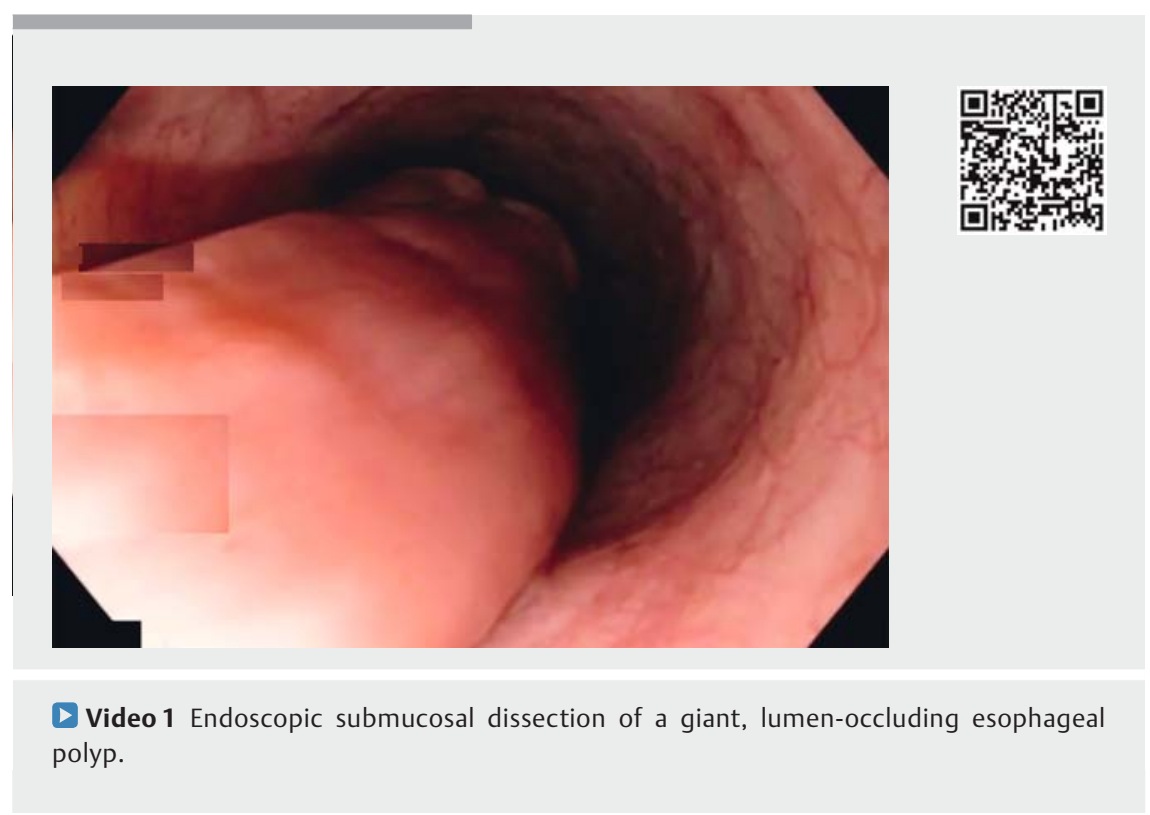

Fibrovascular polyps tend to appear as lesions of up to $7 \mathrm{~cm}$ in length, and cause symptoms that range from dysphagia to episodes of asphyxiation due to prolapse into the respiratory tract $[1,2]$. Traditionally, surgical treatment is performed because there is a risk of hemorrhaging during endoscopic resection [3].

A 48-year-old woman with dysphagia and progressive retrosternal pain for 6 months underwent an upper endoscopy, which showed an esophageal polyp of
$12 \mathrm{~cm}$ in length occupying $80 \%$ of the lumen ( $\mathbf{F i g . 1 )}$. The histology confirmed a fibrovascular polyp.

We carried out another upper endoscopy under sedation. First, we identified the pedicle. Clips were placed, and the submucosal dissection was initiated sequentially with a needle-knife, being careful to identify all of the feeder vessels. Selective hemostasis was performed with coagulation forceps (Coagrasper; Olympus, Tokyo, Japan) in endocut mode. After

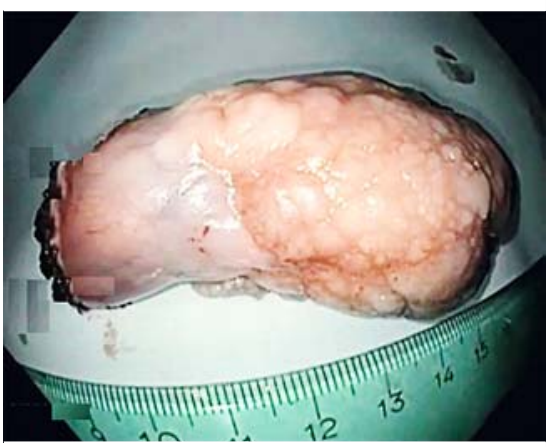

- Fig. 2 Peroral extraction of the resected polyp.

careful dissection of all tissue, the polyp was completely removed in one piece $(\triangleright$ Video 1). Peroral extraction was carried out using a net ( $\triangleright$ Fig. 2 ). The pathology report confirmed a fibrovascular polyp.

The postoperative course occurred without any incidents, and endoscopic follow-up 2 months later showed a scar with no signs of recurrence.

Endoscopy_UCTN_Code_TTT_1AO_2AG

Competing interests

None

The authors

Mario Rey Ferro, Raul Pinilla Morales

Department of Gastrointestinal Surgery and Digestive Endoscopy, National Cancer Institute, Bogotá, Colombia

\section{Corresponding author}

Mario Rey Ferro, MD

Department of Gastrointestinal Surgery and Digestive Endoscopy, National Cancer Institute, Calle 91\#19c-55. Cons. 609, Bogotá 1, Colombia

Fax: +57-1-2320219

reyferro1@gmail.com 


\section{References}

[1] Lee SY, Chan WH, Sivanandan R et al. Recurrent giant fibrovascular polyp of the esophagus. World J Gastroenterol 2009; 15: 3697-3700

[2] Park JS, Bang BW, Shin J et al. A case of esophageal fibrovascular polyp that induced asphyxia during sleep. Clin Endosc 2014; 47: $101-103$

[3] Mishra PK, Goel N, Saluja SS et al. Management of giant fibrovascular polyp of esophagus. Am Surg 2012; 78: E538 -E540
Bibliography

DOI https://doi.org/10.1055/a-0830-4513

Published online: 1.4.2019

Endoscopy 2019; 51: E151-E152

(c) Georg Thieme Verlag KG

Stuttgart · New York

ISSN 0013-726X
ENDOSCOPY E-VIDEOS

https://eref.thieme.de/e-videos

回回 Endoscopy E-Videos is a free access online section, reporting 回: on interesting cases and new techniques in gastroenterological endoscopy. All papers include a high quality video and all contributions are freely accessible online.

This section has its own submission website at

https://mc.manuscriptcentral.com/e-videos 